\title{
Linkage analysis of multiple sclerosis with candidate region markers in Sardinian and Continental Italian families
}

\author{
Sandra D 'A Ifonso ${ }^{1}$, L orenza N isticò ${ }^{2}$, Patrizia Zavattari ${ }^{1}$, M aria G iovanna M arrosu ${ }^{3}$, \\ R affaele $M$ urru ${ }^{3}$, M arina $L$ ai $^{3}$, L uca M assacesi ${ }^{4}$, Clara B allerini $^{4}$, D onella $G$ estri ${ }^{4}$, \\ M arco Salvetti ${ }^{5}$, G iovanni R istori ${ }^{5}$, R oberto Bomprezzi ${ }^{5}$, Maria Trojano ${ }^{6}$, \\ Maria Liguori ${ }^{6}$, D omenico Gambi ${ }^{7}$, A Ido Quattrone ${ }^{8}$, D oriana Fruci ${ }^{2}$, Francesco Cucca ${ }^{9}$, \\ Patricia Momigliano R ichiardi ${ }^{1}$ and Roberto Tosi $^{2}$

\footnotetext{
${ }^{1}$ Chair of Human G enetics, D epartment of M edical Sciences, U niversity of Piemonte O rientale 'A . A vogadro', Novara

${ }^{2}$ Institute of Cell Biology, CNR, Rome

${ }^{3}$ Chair of N europhysiopathology, D epartment of N euroscience, U niversity of Cagliari

${ }^{4} \mathrm{D}$ epartment of N eurological and P sychiatric Sciences, U niversity of Firenze

${ }^{5} \mathrm{D}$ epartment of N eurological Sciences, U niversity 'L a Sapienza', R ome

${ }^{6} \mathrm{D}$ epartment of N eurological and Psychiatric Sciences, University of Bari

${ }^{7}$ D epartment of Clinical Neurology, University 'G. D'A nnunzio', Chieti

${ }^{8} \mathrm{D}$ epartment of M edical Sciences, U niversity of Catanzaro and Institute of Experimental M edicine and B iotechnology, CNR

II nstitute of Clinics and B iology of G rowing A ge, University of Cagliari, I taly
}

\begin{abstract}
Previous genome screens in multiple sclerosis have shown some evidence of linkage in scattered chromosomal regions. A lthough in no case the evidence of each single study was compelling and although in general the linkage 'peaks' of the different studies did not coincide, some regions can be considered likely candidates for the presence of $M S$ risk genes because of the clustering of MLS scores and homology with eae loci. We performed a linkage analysis of markers in these regions and of intragenic markers of some individual candidate genes (H LA DRB 1, CTLA-4, IL9, APOE, BCL2, TNFR2). For the first time, Southern E uropean populations were targeted, namely C ontinental Italians and Sardinians. A total of 69 multiplex families were typed for $\mathbf{6 7}$ markers by a semi-automatic fluorescence-based assay. R esults were analysed for linkage by two non-parametric tests: GE NE H U NTER and SimIBD. In general, the linkage scores obtained were low, confirming the conclusion that no gene is playing a major role in the disease. However, some markers, in 2p11, 3q21.1, 7p15.2 and 22q13.1 stood out as promising since they showed higher scores with one or the other test. This stimulates further association analysis of a large number of simplex families from the same populations.
\end{abstract}

Keywords: multiple sclerosis; linkage analysis; multiplex families

Correspondence: R oberto Tosi, I stituto di B iologia Cellulare, $V$ ia $R$ amarini 32, 00016 M onterotondo Scalo, R ome, I taly. Tel: +390690091201; Fax: +390690091260; E-mail: rtosie@ibc.rm.cnr.it

R eceived 10 A ugust 1998; revised 10 ctober 1998; accepted 6 N ovember 1998 


\section{Introduction}

Multiple sclerosis (MS) is a complex disease of the central nervous system (CNS) characterised by relapsing remitting or chronic progressive course and inflammatory demyelinating lesions of CNS white matter. In western countries MS represents, after trauma, the most frequent cause of disability among young adults. ${ }^{1}$ A large amount of evidence indicates that an immunemediated mechanism is responsible for damage to the nervous tissue. ${ }^{2-4}$

MS is caused by an interplay of environmental and genetic factors. Their relative weight can be evaluated by three approaches: population epidemiology, twin concordance and family aggregation. E pidemiological studies show that environmental factors, likely infectious agents, play a major role as demonstrated by change in $\mathrm{MS}$ risk consequent on migration from high to low risk areas and vice versa, and occasional 'epidemics' in small communities after contact with groups of individuals from high risk areas. ${ }^{5} \mathrm{H}$ owever, they also demonstrate the importance of genetic factors in that some ethnic groups maintain their relative resistance to $\mathrm{MS}$ even when they reside in areas where MS is common (eg Gypsies in Hungary, Blacks and O rientals in USA, Maoris in N ew Zealand, Lapps in Scandinavia). ${ }^{6}$

Twin studies clearly demonstrate the role of genetic factors since $M Z$ concordance is substantially above DZ concordance ( $25-30 \%$ versus $3 \%$ ) but also show the importance of the environment since the concordance level in $M Z$ twins is well below $100 \%$.

Remarkably, familial aggregation is largely controlled by genetic factors since the disease risk in relatives closely follows the degree of genetic similarity with the proband, according to polygenic inheritance model, and is proportional to their kinship coefficient also for second and third degree relatives who are less likely to have shared the same environmental exposure. ${ }^{7} \mathrm{M}$ ore direct evidence that familial aggregation is mostly or completely due to genetic factors comes from adoption $^{8}$ and half-sib ${ }^{9}$ studies. The current interpretation is that although MS is heavily influenced by environmental factors, they are not family specific. $\mathrm{H}$ ence the study of multiple-case families is most likely to provide information on genetic factors. The rather high level of $\lambda s(20-40)$ compares favorably with that of type 1 diabetes $(\lambda s=15)$ in which linkage studies have been largely successful. M oreover, in M S the contribution of $\mathrm{MHC}$ is lower than in diabetes leaving more 'room' for the contribution of other genes.
Prompted by this promising background, a systematic search of MS genes was undertaken in several populations by whole genome linkage screens. The conclusions were that no predominant susceptibility gene is involved, that no locus (not even HLA) can be consistently shown to be M S linked in all screens and that the presence of minor loci (with $\lambda s<1.5$ ) cannot be excluded in any sizeable portion of the genome.

$\mathrm{N}$ evertheless, for some chromosome regions multiple indications of possible linkage have accumulated, particularly on $2 p, 5 p, 5 q, 17 q$ and $19 q{ }^{10,11}$ They are weak, in no case reaching a level of 'suggestive evidence'12 and they do not necessarily concern the same marker in the different screens, but in some cases they coincide with regions of homology to eae genes in the mouse ${ }^{13}$ and in the rat. ${ }^{14}$ Thus these regions are a logical starting point for further analysis and replication attempts.

We performed a linkage analysis in Southern E uropean populations with the following rationale. All studies have been so far done on N orthern Caucasoids. However, linkage analysis is very sensitive to the disease gene frequency. For a gene of moderate to low effect 10-100 fold fewer sib pairs may be needed to show linkage in a population where the frequency of the disease allele is intermediate compared with one where it is either high or low. ${ }^{15}$ Therefore the choice of the population can be critical. We experienced with IDDM 12 in type 1 diabetes a precedent in which a genomic region, where weak or no evidence for linkage was reported in Northern Caucasoids, showed significant linkage in Southern Caucasoids. ${ }^{16,17}$

The present study includes a panel of multiplex families from Continental Italy and from Sardinia. Sardinians belong to a rather homogeneous and isolated population with a genetic background substantially different from that of other populations; ${ }^{18}$ features that are relevant in view of subsequent association studies. Moreover, the incidence of MS in Sardinia is higher than in other I talian regions and close to $\mathrm{N}$ orthern E uropean incidence rates. ${ }^{19,20}$

$M$ arkers in candidate regions were selected on the basis of previous linkage data and included a few candidate genes, namely HLA-DRB 1, CTLA-4, IL 9, APOE, BCL 2 and TNFR2. HLA was chosen as the only locus that showed consistently genetic association and, less consistently, linkage to M S. CTL A-4 has been shown to be associated with IDDM ${ }^{16}$ and other autoimmune diseases ${ }^{21}$ and, like BCL 2 and TNFR2, is involved in the regulation of lymphocyte activation. IL 9 is a representative of the IL gene cluster that 
resides within an eae-linked region in the rat. ${ }^{14} \mathrm{APOE}$ is located in a region showing some evidence of linkage to $\mathrm{MS}$ and its variation is relevant in other neurological diseases.

\section{Materials and Methods}

\section{Diagnostic Criteria}

Index patients and affected siblings with a diagnosis of definite multiple sclerosis according to Poster et al, ${ }^{22}$ were enrolled in the H ospitals of B ari, Cagliari, Catanzaro, Chieti, Florence and R ome universities. $\mathrm{E}$ ach patient was submitted to clinical evaluation by a trained neurologist and to cerebro spinal fluid and magnetic resonance imaging analysis.

\section{Families}

$R$ elatives of index cases and affected siblings were recruited in the same centres as part of a programme for collecting genomic material from Italian MS multiplex families sponsored by the Italian Multiple Sclerosis Foundation (FISM). Details are shown in Table 1. Enrolment of patients and relatives followed their informed consent.

\section{Genotyping}

DNA was extracted from peripheral blood by standard techniques. Samples were analysed for 67 microsatellites grouped in six pools. Preference was given to the markers studied in the previous genome screens. M ost of them (49) were $(C A) n$ repeats belonging to the $G$ enethon map. ${ }^{23}$ The remainder were included in the $\mathrm{CHLC}$ map. ${ }^{24}$ Polymerase chain reaction (PCR) was performed in $10 \mu \mathrm{l}$ using $40 \mathrm{ng}$ of DNA, $10 \mathrm{~mm}$ Tris- $\mathrm{HCl}$ pH 8.3, $50 \mathrm{~mm} \mathrm{KCl}, 1.5-2 \mathrm{~mm} \mathrm{M} \mathrm{gCl2,}$ $200 \mathrm{~mm}$ of each dNTP, 4 pm of each primer and $0.5 \mathrm{U}$ of Taq DNA polymerase.

Forward primers were $5^{\prime}$-labelled with one of the four A BI (Forster City, CA, USA) fluorescence dyes (FAM, HEX, TET, Tamra). PCR reactions were performed in a 9600 Perkin E Imer (Norwalk, CT, USA) thermal cycler for $30 \mathrm{~s}$ at $95^{\circ} \mathrm{C}$, $30 \mathrm{~s}$ at $52-57^{\circ} \mathrm{C}, 30 \mathrm{~s}$ at $72^{\circ} \mathrm{C}$ for $30 \mathrm{cycles}$, followed by a final extension step of $5 \mathrm{~min}$.

PCR products of 11-13 microsatellites were pooled according to their non-overlapping fluorescence colour and size ranges. The pools were treated with T4 DNA polymerase $\left(0.8 \mathrm{U}\right.$ in $3 \mu \mathrm{l}$ at $37^{\circ} \mathrm{C}$ for $\left.30 \mathrm{~min}\right)$. Two $\mu \mathrm{l}$ pool were added to $3 \mu \mathrm{l}$ of loading buffer (72\% formamide, $14 \%$ dextran blue, 14\% GENESCA N-350 Tamra or GENESCAN-350 Rox $(\mathrm{A} B \mathrm{I})$ as an internal size standard), denatured at $95^{\circ} \mathrm{C}$ for
5 min and loaded on a $6 \%$ denaturing polyacrylamide gel. E lectrophoresis was performed in a $24 \mathrm{~cm}$ gel for $8 \mathrm{~h}$ at $2500 \mathrm{~V}$ $40 \mathrm{~mA}$ and $30 \mathrm{~W}$ in an $\mathrm{ABI} 373 \mathrm{~A}$ sequencer. Data were collected and sized using the $G$ enescan 672 and $G$ enotyper 2.1 software $(A B I)$.

$D$ ata obtained from different gel electrophoreses were tested for uniformity by comparing the allele specific size values assigned to two reference samples loaded in each gel, namely the CEPH 134702 cell line and a local DNA sample.

A llele standardisation and control of family segregation were performed using the GAS package version 2.0 (A lan Young, Oxford U niversity, 1993-95).

HLA-DRB 1 typing was performed by the Sequence Specific Primer (SSP) technique (Dynal DR low resolution SSP; Dynal, Oslo, Norway) and by the sequence specific oligonucleotide (SSO) technique according to the XII H istocompatibility Workshop protocol.

A POE genotypes were determined by digestion with the restriction enzyme $\mathrm{H}$ hal of the amplified fragment containing the polymorphic exon IV of the APOE gene (primers: 5'-TCG GCC GCA GGG CGC TGA TGG-3' and 5'-CTC GCG GGC CCC GGC CTG GTA - 3'). Electrophoresis on $2 \%$ M etaphor (FMC, Philadelphia, PA, USA) agarose plus $1 \%$ standard agarose and staining with ethidium bromide were used.

\section{Statistical Analysis}

The data were analysed for linkage by two non-parametric methods.

The GENEHUNTER program ${ }^{25}$ was adopted because it allows extraction of linkage information from all relatives, including families with affected members other than sibs, and lacking one or both parents. NPL all scores were determined. Single-point analysis was performed for all markers. The program calculates $P$ values based on the asymptotically normal statistic. NPL scores for $X$-linked markers were calculated by the xgh version of the program. Multipoint analysis was also performed in the chromosomal regions where several closely located markers were tested. G enetic distances between the markers were calculated by the LIK 2P module of the GAS 2.0 package and were in substantial agreement with the Généthon map distances from $\mathrm{CEPH}$ families. When the linkage lod score was not significant (i.e. < 3) we utilised the sex-averaged genetic distances from the $\mathrm{G}$ énéthon map ${ }^{23}$ for $\mathrm{G}$ énéthon markers and genetic distances from LDB database ${ }^{26}$ for the remaining markers, except for M A O B whose distances were derived from $D$ avies et al. ${ }^{27}$

Table 1 Composition of tested multiplex families

\begin{tabular}{|c|c|c|c|c|c|c|c|c|c|}
\hline & $\begin{array}{l}\text { Total no. } \\
\text { of families }\end{array}$ & $\begin{array}{l}\text { Sib } \\
\text { pairs }\end{array}$ & $\begin{array}{l}\text { Sib } \\
\text { trios }\end{array}$ & $\begin{array}{l}\text { with } 2 \\
\text { parents }\end{array}$ & $\begin{array}{l}\text { with } 1 \\
\text { parent }\end{array}$ & $\begin{array}{l}\text { without } \\
\text { parents }\end{array}$ & $\begin{array}{c}\text { families with } \\
\text { other affected } \\
\text { relatives }\end{array}$ & $\begin{array}{l}\text { no. affected } \\
\text { individuals }\end{array}$ & $\begin{array}{c}\text { no. analysed } \\
\text { individuals }\end{array}$ \\
\hline $\begin{array}{l}\text { Continental } \\
\text { Italy }\end{array}$ & 41 & 37 & 1 & 22 & 9 & 7 & $3^{a}$ & 87 & 186 \\
\hline Sardinia & 28 & 24 & 2 & 13 & 8 & 5 & $2^{b}$ & 57 & 158 \\
\hline
\end{tabular}

one uncle/nephew pair and two first cousin pairs; ${ }^{\text {f }}$ first cousins. 
$\operatorname{Sim} I B D^{28}$ uses a conditional simulation approach to produce an empirical null distribution and empirical $P$ values. Like GENEHUNTER it uses all available genotypes in unaffected individuals to measure identity-by-descent (IBD) sharing. In some instances, it possesses a power of extracting linkage information higher than GE NEHUNTER -A II statistics. ${ }^{29}$ The $1 /$ sqrt(p) weighting function was used, where $p$ is the population frequency of a given allele, with a number of replicates of 1000 .

\section{Results}

Two panels of multiplex families, Sardinians ( 28 families) and Continental Italians (41 families), were analysed by GENEHUNTER and SimIBD. Each test extracts subsets of the complete linkage information from the available data set and they may increase the power of the overall analysis and reduce the risk of type II errors.

A summary of the data is provided in Table 2. This is so organised as to facilitate comparison with data from other studies. It reports the cytogenetic localisation of the tested markers as derived from the LDB integrated map; ${ }^{26}$ the genetic distances between the markers; the $N L P_{\text {all }}$ scores obtained by GENEHUNTER; the empirical $P$ values calculated by SimIBD and the linkage scores in genome screens performed in USA / French, ${ }^{30}$ U K, ${ }^{31}$ Canadian, ${ }^{32}$ and Finnish families. ${ }^{11,33}$ Linkage data are reported for each of the two sets of families, Sardinian (Sard) and Continental Italians (Cont) and for both sets combined (total).

O nly the single point NPL statistics is shown. NPL probability levels were in all cases $>0.05$ except for D 7S484 in the combined set (NPL $1.66 \mathrm{P}=0.048$ ). Suggestions of linkage, ie N PL scores equal to or higher than 1.0 and/or Siml BD P values $<0.05$ in at least one family set were found in 2p11, 2q33 (CTLA-4), 3p11, $3 q 21,5 p 15,5 p 11,5 q 12,5 q 14,6 p 21$ (H L A ), 7p15, 17q12, 22q13, Xp11. They are highlighted in Table2. Mostly negative scores were observed in chromosomes $1 p, 3 p$, $4 q, 7 q, 12 p, 12 q, 14 q, 17 p, 19 q, X q$ and for the individual candidate genes TNFR2, IL 9, BCL 2 and APOE. The D 17S807 marker in 17q21 was particularly interesting because it showed suggestive linkage evidence both in the Finnish ${ }^{11}$ and in the $U \mathrm{~K}^{31}$ screens. We obtained an NPL score of about 0.9 , lower than the relatively high scores of the previous studies, but close to our arbitrary threshold of 1.0.

Multipoint NPL analysis in the regions where multiple markers were tested did not substantially increase the linkage scores, despite acceptable levels of extraction of information content. The multipoint data are shown only for chromosome 5 (Figure 1). With a level of information extraction of about $70 \%$, the maximum $N P L_{\text {all }}$ score observed was $1.13(P=0.13)$ in the Sard set in the q14 region near the D5S815 microsatellite. The same marker gave an MLS 1.14 in the US/FR study. Low or negative scores were given by other chromosome 5 regions, even though this chromosome appeared the most promising as judged from data of linkage in the other studies and from the homology of the $\mathrm{p} 14-\mathrm{p} 12$ region with the eae2 mouse region.

\section{Discussion}

This is the first linkage study in MS performed on Southern European Caucasoids. O ur data provide some evidence of linkage in regions that were singled out by previous studies. The linkage scores are in general low, yet positive and not dissimilar from those expected from genes of low effect studied in populations of limited sizes. In fact, even the contribution of $H L A$, that is supported by association studies in several populations, was not detected by linkage in all studies and, within each study, in all sets. ${ }^{11,30-33}$ Likewise, we observed an NPL score $>1$ with HLA-DRB 1 in Continental Italians and a lower, although still positive score in Sardinians, even though a significant HLA association was observed in both populations ${ }^{34}$ (CB unpublished results). The relative contribution of HLA to familial aggregation can be estimated in the Continental families where $19 \%$ of sibships share no alleles $\mathrm{IBD}$. Following $\mathrm{R}$ isch ${ }^{35}$ and assuming a multiplicative model and $a \lambda s$ for $M S=20$, the HLA contribution was $9.3 \%$ by the calculation method proposed by Todd. ${ }^{36}$ This is comparable to the figure of $13.5 \%$ deduced from the data of Sawcer et $\mathrm{al}^{31}$ under the same assumptions but much lower than the data of Risch $(29 \%)$ and of $\mathrm{H}$ aines et $\mathrm{al}^{37}(54 \%)$. The reasons for these wide fluctuations are not easily understood and could reflect marked population variations.

The problem of replication is strictly related to the magnitude of the genetic effect to be detected. The chance of replication decreases not linearly, but according to the square of the effect of the gene. A II linkage studies so far indicate the absence of any gene with a predominant effect in MS. However, the evidence for the presence of MS genes and for them accounting for most of the family aggregation is overwhelming. ${ }^{8-9}$ A ssuming that 10 (or more) epistatic genes of equal effect contribute a $\lambda s$ of about 30 , each of them would have a $\lambda s=1.4$ (or less). Under these conditions, 
Table 2 Single point linkage data in Sardinians, Continental I talians and combined sets

\begin{tabular}{|c|c|c|c|c|c|c|c|c|c|c|c|c|c|}
\hline \multirow[b]{2}{*}{ Chr. } & \multirow[b]{2}{*}{$\begin{array}{l}\text { Cytogenetic } \\
\text { band }\end{array}$} & \multirow[b]{2}{*}{ M arker } & \multirow[b]{2}{*}{$\begin{array}{l}\text { D istance* } \\
\text { CM }\end{array}$} & \multicolumn{3}{|c|}{ GENE HUNTER (NPL) } & \multicolumn{3}{|c|}{ SIMIBD (P) } & \multirow{2}{*}{$\begin{array}{c}\text { UK } \\
\text { MLS }\end{array}$} & \multirow{2}{*}{$\begin{array}{l}\text { US/FR } \\
\text { lod } \\
\text { score }\end{array}$} & \multirow{2}{*}{$\begin{array}{c}C \\
M L S\end{array}$} & \multirow{2}{*}{$\begin{array}{c}\text { F } \\
\text { lod } \\
\text { score }\end{array}$} \\
\hline & & & & Total & Sard. & Cont. & Total & Sard. & Cont. & & & & \\
\hline 1 & $\begin{array}{l}\text { p36.22 } \\
\text { p36.12 } \\
\text { p34.3 } \\
\text { p22.2 }\end{array}$ & $\begin{array}{l}\text { TNFR } 2 \\
\text { D 1S199 } \\
\text { D 1S201 } \\
\text { D 1S216 }\end{array}$ & $\begin{array}{l}24.4 \\
22.7 \\
>50^{b}\end{array}$ & $\begin{array}{r}0.10 \\
-0.62 \\
-0.67 \\
-0.01\end{array}$ & $\begin{array}{r}-0.94 \\
-0.96 \\
0.18 \\
-0.21\end{array}$ & $\begin{array}{r}0.91 \\
-0.01 \\
-1.03 \\
0.16\end{array}$ & $\begin{array}{l}0.10 \\
0.43 \\
0.80 \\
0.12\end{array}$ & $\begin{array}{l}0.25 \\
0.21 \\
0.30 \\
0.34\end{array}$ & $\begin{array}{l}0.55 \\
0.59 \\
0.88 \\
0.16\end{array}$ & $\begin{array}{l}1.2 \\
0.93 \\
1.0\end{array}$ & & 0.95 & \\
\hline 2 & $\begin{array}{l}\mathrm{p} 16.3 \\
\mathrm{p} 11.2 \\
\mathrm{p} 11.1 \\
\mathrm{q} 33.1\end{array}$ & $\begin{array}{l}\text { D 2S119 } \\
\text { D 2S169 } \\
\text { D 2S139 } \\
\text { CTLA -4 }\end{array}$ & $\begin{array}{c}41^{a} \\
2.6 \\
>50^{b}\end{array}$ & $\begin{array}{r}-0.98 \\
0.57 \\
0.98 \\
0.67\end{array}$ & $\begin{array}{r}-0.26 \\
0.22 \\
0.92 \\
1.04\end{array}$ & $\begin{array}{r}-1.07 \\
0.56 \\
0.53 \\
0.01\end{array}$ & $\begin{array}{l}0.7 \\
\mathbf{0 . 0 1 9} \\
0.8 \\
0.39\end{array}$ & $\begin{array}{l}0.17 \\
0.18 \\
0.52 \\
0.52\end{array}$ & $\begin{array}{l}0.88 \\
\mathbf{0 . 0 4 4} \\
0.85 \\
0.34\end{array}$ & $\begin{array}{l}1.3 \\
1.4\end{array}$ & & 1.24 & \\
\hline 3 & $\begin{array}{l}\mathrm{p} 21.2 \\
\mathrm{p} 14.3 \\
\mathrm{p} 14.1 \\
\mathrm{p} 13 \\
\mathrm{p} 11.1 \\
\mathrm{q} 21.1 \\
\mathrm{q} 21.3 \\
\mathrm{q} 22.2\end{array}$ & $\begin{array}{l}\text { D 3S1289 } \\
\text { D 3S1300 } \\
\text { D 3S1285 } \\
\text { D 3S1261 } \\
\text { D 3S1595 } \\
\text { D 3S1278 } \\
\text { D 3S3607 } \\
\text { D 3S1309 }\end{array}$ & $\begin{array}{c}9 \\
10 \\
6 \\
18 \\
16 \\
14 \\
14\end{array}$ & $\begin{array}{r}0.18 \\
0.13 \\
-0.03 \\
-0.98 \\
0.43 \\
1.10 \\
-0.25 \\
-0.21\end{array}$ & $\begin{array}{r}-0.41 \\
-0.30 \\
0.14 \\
-1.00 \\
-0.49 \\
0.85 \\
-0.32 \\
0.01\end{array}$ & $\begin{array}{r}0.58 \\
0.41 \\
-0.16 \\
-0.48 \\
0.96 \\
0.73 \\
-0.06 \\
-0.29\end{array}$ & $\begin{array}{c}0.16 \\
0.24 \\
0.74 \\
\text { nt } \\
0.31 \\
0.42 \\
0.20 \\
0.74\end{array}$ & $\begin{array}{c}0.34 \\
0.23 \\
0.58 \\
\text { nt } \\
0.89 \\
0.45 \\
0.80 \\
0.65\end{array}$ & $\begin{array}{c}0.15 \\
0.44 \\
0.68 \\
\mathrm{nt} \\
0.15 \\
0.46 \\
0.16 \\
0.71\end{array}$ & $\begin{array}{l}1.2 \\
1.3 \\
1.1 \\
0.8\end{array}$ & & 0.99 & \\
\hline 4 & $\begin{array}{l}q 32.1 \\
q 35.2\end{array}$ & $\begin{array}{l}\text { D 4S415 } \\
\text { D 4S426 }\end{array}$ & $\begin{array}{c}9 \\
10\end{array}$ & $\begin{array}{l}-1.07 \\
-0.40\end{array}$ & $\begin{array}{l}-1.27 \\
-0.19\end{array}$ & $\begin{array}{l}-0.32 \\
-0.37\end{array}$ & $\begin{array}{l}0.95 \\
0.46\end{array}$ & $\begin{array}{l}0.9 \\
0.72\end{array}$ & $\begin{array}{l}0.79 \\
0.28\end{array}$ & 1.4 & & & \\
\hline 5 & $\begin{array}{l}\text { p15.33 } \\
\text { p15.31 } \\
\text { p15.2 } \\
\text { p15.1 } \\
\text { p13.1 } \\
\text { p12 } \\
\text { p11 } \\
\text { q11.1 } \\
\text { q12.1 } \\
q 14.1 \\
q 14.3 \\
q 31.1 \\
q 31.1\end{array}$ & $\begin{array}{l}\text { D 5S417 } \\
\text { D 5S406 } \\
\text { D 5S416 } \\
\text { D 5S655 } \\
\text { D 5S477 } \\
\text { D 5S455 } \\
\text { D 5S1968 } \\
\text { D 5S427 } \\
\text { D 5S424 } \\
\text { D 5S428 } \\
\text { D 5S815 } \\
\text { IL 9 } \\
\text { D 5S393 }\end{array}$ & $\begin{array}{c}6 \\
17 \\
7 \\
12 \\
7 \\
16 \\
8 \\
15 \\
13^{\mathrm{a}} \\
4 \\
47^{\mathrm{a}} \\
1.5 \\
2\end{array}$ & $\begin{array}{r}0.93 \\
-0.27 \\
-1.06 \\
-0.85 \\
-0.41 \\
-0.29 \\
0.55 \\
0.50 \\
0.51 \\
-1.27 \\
-0.55 \\
0.33 \\
-0.13\end{array}$ & $\begin{array}{r}-0.00 \\
-0.21 \\
-0.83 \\
-0.23 \\
0.06 \\
-0.67 \\
-0.33 \\
0.56 \\
1.00 \\
0.11 \\
1.15 \\
0.70 \\
0.10\end{array}$ & $\begin{array}{r}1.24 \\
0.18 \\
-0.68 \\
-0.93 \\
-0.60 \\
0.20 \\
1.03 \\
0.18 \\
-0.19 \\
-1.80 \\
-1.75 \\
-0.16 \\
-0.27\end{array}$ & $\begin{array}{l}0.10 \\
0.85 \\
0.95 \\
0.96 \\
0.88 \\
0.59 \\
0.23 \\
0.70 \\
0.13 \\
0.62 \\
0.78 \\
0.24 \\
0.94\end{array}$ & $\begin{array}{l}0.80 \\
0.93 \\
0.70 \\
0.81 \\
0.65 \\
0.67 \\
0.62 \\
0.51 \\
\mathbf{0 . 0 2} \\
0.29 \\
0.16 \\
0.45 \\
0.91\end{array}$ & $\begin{array}{l}\mathbf{0 . 0 0 2} \\
0.50 \\
0.93 \\
0.94 \\
0.86 \\
0.45 \\
0.13 \\
0.72 \\
0.76 \\
0.84 \\
0.98 \\
0.24 \\
0.85\end{array}$ & $\begin{array}{l}2.5 \\
1.3 \\
1.0\end{array}$ & 1.14 & $\begin{array}{l}1.8 \\
4.2\end{array}$ & $\begin{array}{l}3.4 \\
\\
1.5 \\
2.2 \\
2.0\end{array}$ \\
\hline 6 & p21.31 & $H L A-D R$ & & 1.26 & 0.56 & 1.17 & 0.36 & 0.54 & 0.31 & & & & \\
\hline 7 & $\begin{array}{l}\text { p15.3 } \\
\text { p15.2 } \\
q 11.23 \\
q 22.1 \\
q 31.31\end{array}$ & $\begin{array}{l}\text { D 7S629 } \\
\text { D 7S484 } \\
\text { D 7S524 } \\
\text { D 7S554 } \\
\text { D 7S523 }\end{array}$ & $\begin{array}{c}19 \\
>50^{b} \\
10 \\
13\end{array}$ & $\begin{array}{r}-0.14 \\
1.66 \\
0.50 \\
0.13 \\
0.14\end{array}$ & $\begin{array}{r}0.36 \\
1.60 \\
-0.37 \\
0.39 \\
0.76\end{array}$ & $\begin{array}{r}-0.48 \\
0.84 \\
0.95 \\
-0.15 \\
-0.44\end{array}$ & $\begin{array}{l}0.35 \\
0.21 \\
0.82 \\
0.13 \\
0.33\end{array}$ & $\begin{array}{l}0.25 \\
0.44 \\
0.77 \\
0.18 \\
0.21\end{array}$ & $\begin{array}{l}0.50 \\
0.09 \\
0.70 \\
0.22 \\
0.69\end{array}$ & $\begin{array}{l}1.6 \\
1.2 \\
0.5\end{array}$ & $\begin{array}{l}2.86 \\
1.11\end{array}$ & $\begin{array}{l}0.38 \\
0.7\end{array}$ & \\
\hline 12 & $\begin{array}{l}\text { p13.31 } \\
\text { p13.31 } \\
\text { p12.3 } \\
\text { p12.3 } \\
\text { p12.3 } \\
\text { p11.1 } \\
\text { q23.2 } \\
\text { q24.33 }\end{array}$ & $\begin{array}{l}\text { D 12S374 } \\
\text { D 12S77 } \\
\text { D 12S364 } \\
\text { D 12S62 } \\
\text { D 12S310 } \\
\text { D 12S87 } \\
\text { PA H } \\
\text { D 12S392 }\end{array}$ & $\begin{array}{c}10 \\
8.8 \\
5.6 \\
3 \\
10 \\
>50^{b} \\
>50^{b}\end{array}$ & $\begin{array}{r}-0.19 \\
-0.38 \\
-0.32 \\
-1.82 \\
-1.91 \\
-0.72 \\
-1.28 \\
0.33\end{array}$ & $\begin{array}{r}-0.04 \\
0.11 \\
0.06 \\
-1.41 \\
-0.81 \\
-0.28 \\
-0.64 \\
-0.01\end{array}$ & $\begin{array}{r}-0.22 \\
-0.61 \\
-0.50 \\
-1.19 \\
-1.84 \\
-0.72 \\
-1.14 \\
0.45\end{array}$ & $\begin{array}{l}0.69 \\
0.73 \\
0.47 \\
0.77 \\
1.00 \\
0.90 \\
0.96 \\
0.17\end{array}$ & $\begin{array}{l}0.63 \\
0.66 \\
0.28 \\
0.78 \\
0.88 \\
0.90 \\
0.68 \\
0.14\end{array}$ & $\begin{array}{l}0.60 \\
0.63 \\
0.64 \\
0.93 \\
1.00 \\
0.62 \\
0.96 \\
0.40\end{array}$ & $\begin{array}{l}0.8 \\
1.0 \\
2.2 \\
1.8 \\
0.6\end{array}$ & $\begin{array}{l}1.56 \\
1.71\end{array}$ & & \\
\hline 14 & q32.33 & D $14 S 292$ & & -0.06 & -0.04 & -0.04 & 0.48 & 0.67 & 0.26 & 1.4 & & & \\
\hline 17 & $\begin{array}{l}\mathrm{p} 11.2 \\
\mathrm{p} 11.1 \\
\mathrm{q} 12 \\
\mathrm{q} 21.33\end{array}$ & $\begin{array}{l}\text { D } 17 S 953 \\
\text { D } 17 S 798 \\
\text { D } 17 S 250 \\
\text { D } 17 S 807\end{array}$ & $\begin{array}{l}17 \\
15 \\
26\end{array}$ & $\begin{array}{l}0.36 \\
0.60 \\
0.55 \\
0.93\end{array}$ & $\begin{array}{r}0.25 \\
-0.07 \\
1.16 \\
0.50\end{array}$ & $\begin{array}{r}0.26 \\
0.86 \\
-0.28 \\
0.80\end{array}$ & $\begin{array}{l}0.31 \\
0.43 \\
0.83 \\
0.19\end{array}$ & $\begin{array}{l}0.75 \\
0.27 \\
0.61 \\
0.29\end{array}$ & $\begin{array}{l}0.13 \\
0.66 \\
0.85 \\
0.14\end{array}$ & $\begin{array}{l}1.5 \\
1.5 \\
0.3 \\
2.7\end{array}$ & & & 2.8 \\
\hline
\end{tabular}


Table 2 continued

\begin{tabular}{|c|c|c|c|c|c|c|c|c|c|c|c|c|c|}
\hline \multirow[b]{2}{*}{ Chr. } & \multirow[b]{2}{*}{$\begin{array}{l}\text { Cytogenetic } \\
\text { band }\end{array}$} & \multirow[b]{2}{*}{ M arker } & \multirow[b]{2}{*}{$\begin{array}{c}\text { D istance* } \\
\text { CM }\end{array}$} & \multicolumn{3}{|c|}{ GENE HUNTER (NPL) } & \multicolumn{3}{|c|}{ SIMIBD (P) } & \multirow{2}{*}{$\begin{array}{l}\text { UK } \\
\text { MLS }\end{array}$} & \multirow{2}{*}{$\begin{array}{l}\text { US/FR } \\
\text { lod } \\
\text { score }\end{array}$} & \multirow{2}{*}{$\begin{array}{c}C \\
M L S\end{array}$} & \multirow{2}{*}{$\begin{array}{c}\text { F } \\
\text { lod } \\
\text { score }\end{array}$} \\
\hline & & & & Total & Sard. & Cont. & Total & Sard. & Cont. & & & & \\
\hline 18 & $q 21.3$ & $B C L-2$ & & 0.27 & -0.19 & 0.57 & 0.46 & 0.78 & 0.19 & & & & \\
\hline 19 & $\begin{array}{l}\text { q13.11 } \\
\text { q13.12 } \\
\text { q13.12 } \\
\text { q13.113 } \\
\text { q13.2 } \\
\text { q13.32 } \\
\text { q13.32 } \\
\text { q13.32 } \\
\text { q13.32 } \\
\text { q13.33 }\end{array}$ & $\begin{array}{l}\text { D 19S49 } \\
\text { D 19S251 } \\
\text { D 19S225 } \\
\text { D 19S220 } \\
\text { D 19S217 } \\
\text { D 19S219 } \\
\text { D 19S606 } \\
\text { A POC2 } \\
\text { A POE } \\
\text { D 19S246 }\end{array}$ & $\begin{array}{c}7 \\
6 \\
9 \\
7 \\
4 \\
7 \\
7 \\
5 b \\
3 b\end{array}$ & $\begin{array}{r}-0.98 \\
0.28 \\
-0.02 \\
0.29 \\
-0.44 \\
-0.01 \\
-0.42 \\
-0.37 \\
-0.27 \\
-0.57\end{array}$ & $\begin{array}{r}-0.26 \\
-0.01 \\
-0.04 \\
0.31 \\
-0.04 \\
-0.59 \\
-0.04 \\
-0.19 \\
-0.37 \\
0.84\end{array}$ & $\begin{array}{r}0.17 \\
0.38 \\
0.00 \\
0.13 \\
-0.55 \\
0.48 \\
-0.50 \\
-0.32 \\
-0.65 \\
-1.43\end{array}$ & $\begin{array}{l}0.69 \\
0.38 \\
0.20 \\
0.51 \\
0.66 \\
0.49 \\
0.61 \\
0.60 \\
0.56 \\
0.34\end{array}$ & $\begin{array}{l}0.72 \\
0.77 \\
0.29 \\
0.40 \\
0.34 \\
0.90 \\
0.43 \\
0.80 \\
0.24 \\
0.10\end{array}$ & $\begin{array}{l}0.52 \\
0.06 \\
0.25 \\
0.61 \\
0.63 \\
0.15 \\
0.68 \\
0.67 \\
0.58 \\
0.74\end{array}$ & $\begin{array}{l}1.1 \\
1.1 \\
1.2\end{array}$ & $\begin{array}{l}1.13 \\
1.47\end{array}$ & & \\
\hline 22 & $\begin{array}{l}q 13.1 \\
q 13.1 \\
q 13.1\end{array}$ & $\begin{array}{l}\text { D 22S283 } \\
\text { PD G F B } \\
\text { D 22S274 }\end{array}$ & $\begin{array}{l}12 \\
14\end{array}$ & $\begin{array}{r}0.92 \\
-0.02 \\
0.01\end{array}$ & $\begin{array}{r}1.01 \\
0.18 \\
-0.86\end{array}$ & $\begin{array}{r}0.36 \\
-0.18 \\
0.73\end{array}$ & $\begin{array}{l}0.11 \\
0.40 \\
0.56\end{array}$ & $\begin{array}{l}\mathbf{0 . 0 4} \\
0.50 \\
0.86\end{array}$ & $\begin{array}{l}0.33 \\
0.36 \\
0.22\end{array}$ & $\begin{array}{l}1.1 \\
1.4 \\
1.2\end{array}$ & & & \\
\hline$x$ & $\begin{array}{l}\text { p11.4 } \\
\text { p11.3 } \\
\text { p11.21 } \\
\text { q21.33 } \\
\text { q23 }\end{array}$ & $\begin{array}{l}\text { D X S1068 } \\
\text { M A OB } \\
\text { D XS991 } \\
\text { D XS990 } \\
\text { DXS1059 }\end{array}$ & $\begin{array}{l}13^{c} \\
18^{c} \\
17^{c} \\
19^{c}\end{array}$ & $\begin{array}{r}-0.84 \\
-0.33 \\
-0.09 \\
0.01 \\
-0.06\end{array}$ & $\begin{array}{r}0.07 \\
1.04 \\
-0.85 \\
-0.83 \\
0.28 \\
\end{array}$ & $\begin{array}{r}-1.19 \\
-1.37 \\
0.63 \\
0.75 \\
-0.33\end{array}$ & $\begin{array}{l}0.97 \\
0.89 \\
0.24 \\
0.59 \\
0.54\end{array}$ & $\begin{array}{l}0.73 \\
0.59 \\
0.61 \\
0.73 \\
0.57\end{array}$ & $\begin{array}{l}0.97 \\
0.88 \\
0.10 \\
0.47 \\
0.45\end{array}$ & $\begin{array}{l}0.3 \\
\\
1.8 \\
1.2 \\
1.7\end{array}$ & & 1.85 & \\
\hline
\end{tabular}

*calculated distances except for ${ }^{a} \mathrm{G}$ enethon map distances; ${ }^{\mathrm{b}} \mathrm{LD} B{ }^{26}{ }^{\mathrm{c}} \mathrm{D}$ avies et al ${ }^{27}$ see $\mathrm{M}$ aterials and $\mathrm{M}$ ethods.

linkage analysis is unlikely to provide significant lod scores with any practical number of multiplex families ${ }^{15}$ and any low level lod score that may be obtained is unlikely to be replicated in independent studies or sets of patients. However, if any of the genes has a somewhat higher effect, eg a $\lambda$ s close to 2 , similar to that of A POE in A Izheimer's disease, ${ }^{38}$ it is still possible that it can be detected by a sample size of the order of a few hundreds, which is already available by combining the multiplex families so far tested (Table 3 ). In the present study, the same markers used by the other groups were tested also in view of a possible metaanalysis. It is desirable that such a combined analysis be performed.

The limitation due to the sample size in any single study and population is apparent considering the multipoint analysis of chromosome 5 in the Sardinian families (Figure 1). The NPL score peak around 5q14, which is absent in Continental Italians, may point to a favourable situation in the Sardinians in terms of frequency of a particular disease allele. However, further linkage analysis is discouraged by the fact that the $28 \mathrm{families}$ tested already represent about $50 \%$ of the total multiplex families in Sardinia.

Why is it important to record 'weak linkage data' despite the seemingly disproportionate effort required?
The hopes of finding 'major genes' have disappeared in M S as well as in other complex diseases. The underlying reasons, beside the low sensitivity of the analytical tools, may also be the presence of strong and difficult to unravel epistatic interactions between different genes. However, there is a recognisable trend towards accumulation of weak linkage evidence on some regions and not on others, with some sharing between different autoimmune diseases. ${ }^{39}$ These 'tips of icebergs' that in some case coincide with 'eae homology regions' may be important pointers to regions where association studies could be undertaken. The low-degree HLA linkage provides a good example. $\mathrm{H}$ istorically, since $\mathrm{HLA}$ is an obvious candidate locus, linkage studies were preceded by association studies. The rather low and scattered linkage scores obtained in the different sets of families, including ours do not represent a proof of involvement of HLA in the disease. However, retrospectively, if they had prompted an association study, the latter would have been successful. O ne can hope that similar weak evidence of linkage in other regions underlies the presence of some disease gene that can be detected by association studies. The latter are per se more sensitive and experimentally easier since they require single-case families. In this regard, some regions stand out from the present work as good candidates, ie 2p11, marked by 
CHROMOSOME 5
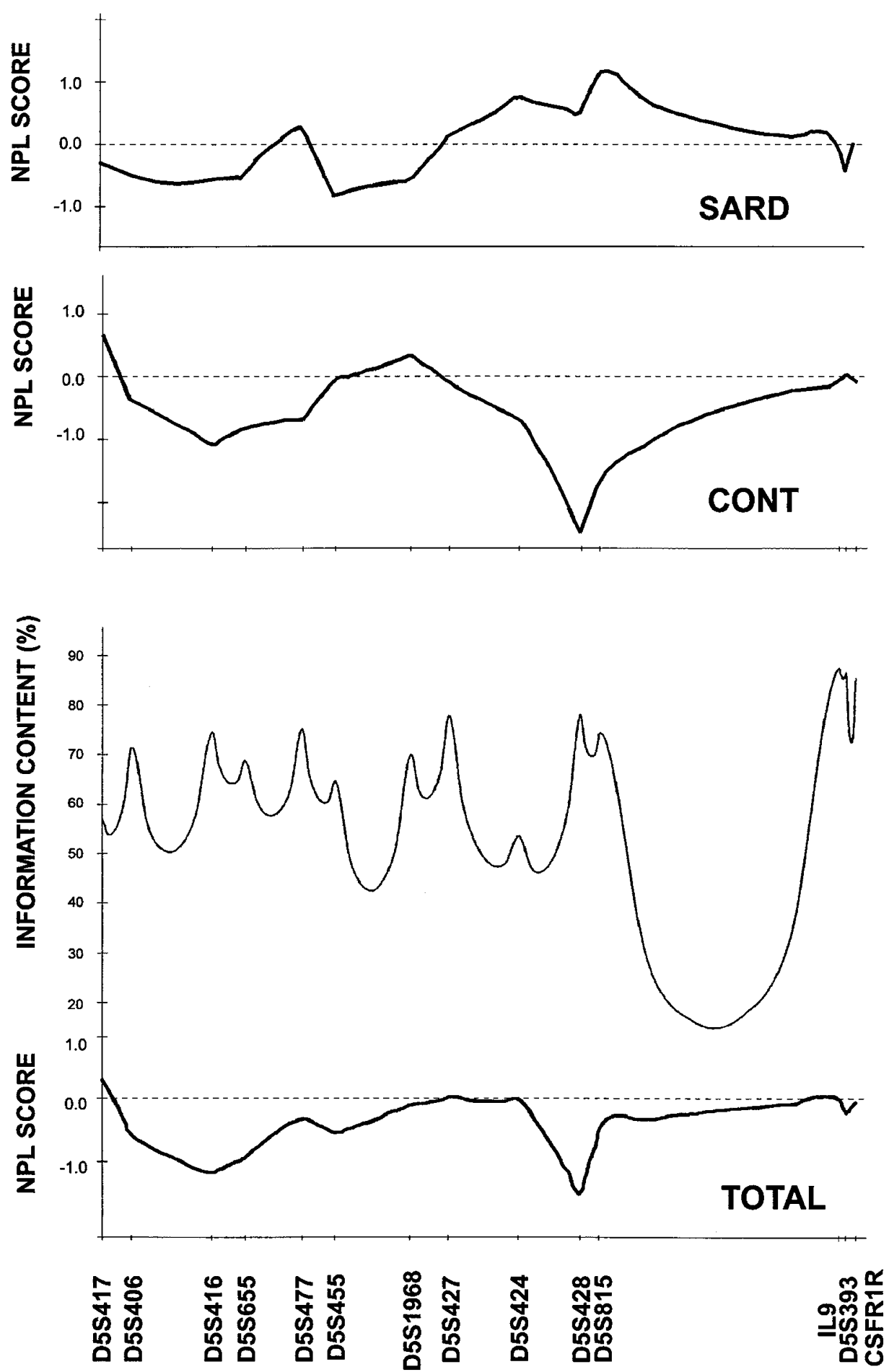

Figure 1 M ultipoint linkage analysis of chromosome 5 markers by G E NE H UNTER. Sardinians (Sard), Continental I talians (Cont) and the two sets combined (Total) are shown. The thick line graphs show multipoint N PL all scores (basal 0 score is indicated by the broken line). The thin line graph shows the percentage of information extracted from the total set of families. The information curves of the two subsets (not shown) were very similar. 
Table 3 N umber of families utilized in M S linkage studies

\begin{tabular}{|c|c|c|c|c|c|c|c|c|c|c|}
\hline Study & R ef & Set & No. fam's & No. pairs & Set & No. fam's & No. pairs & Set & No. fam's & No. pairs \\
\hline $\begin{array}{l}\text { UK } \\
\text { US/FR } \\
\text { Can } \\
\text { Fin } \\
\text { It }\end{array}$ & $\begin{array}{l}\text { Sawcer et } \mathrm{al}^{34} \\
\mathrm{H} \text { aines et } \mathrm{al}^{32} \\
\text { E bers et al } \\
\text { Kuokkanen et al } \\
\text { present study }\end{array}$ & $\begin{array}{c}1 \\
1 \\
1 \\
\text { Cont }\end{array}$ & $\begin{array}{r}129 \\
52 \\
61 \\
21 \\
41\end{array}$ & $\begin{array}{r}143 \\
81 \\
100 \\
24 \\
39\end{array}$ & $\begin{array}{l}2 \\
2 \\
2\end{array}$ & $\begin{array}{l}98 \\
23 \\
42\end{array}$ & $\begin{array}{r}128 \\
45 \\
44 \\
\\
28\end{array}$ & 3 & 72 & 78 \\
\hline Total & & A II sets & 567 & 710 & & & & & & \\
\hline
\end{tabular}

microsatellites D2S169 and D 2S139, 3q21 (microsatellite D3S1278), 7p15 (microsatellite D 7S484) and 22q13 (microsatellite D 22S283). 7p15 is especially appealing since it is homologous to a region harbouring a rat eae locus ${ }^{14}$ and coincides with a region where markers linked to several autoimmune diseases (MS, Crohn disease and asthma) are clustered. ${ }^{39}$ M oreover, our data support previous results indicating that there might be a candidate susceptibility locus in 17q21.3 (microsatellite D 17S807). ${ }^{11}$

In conclusion, we think that the present data provide some additional evidence for the presence of linkage to MS in selected genomic regions and also provide sufficient ground for the collection of a large number of simplex families in Sardinia and in Continental I taly in which to test for genetic association by a dense array of markers.

\section{Acknowledgements}

This work was supported by grants from the Italian M ultiple Sclerosis Foundation (FISM), by the National Project on M ultiple Sclerosis of the Istituto Superiore di Sanità and by M U R ST. The help of D rs R ichard B utler and Walter R olando in the implementation of the statistical programs is gratefully acknowledged.

\section{References}

1 Poser CM: The epidemiology of multiple sclerosis: a general overview. A nn Neurol 1994; 36 (S2): S180-S193.

2 Reder AT, A rnason BGV: Immunology of multiple sclerosis. In: Vinken PJ, Bruyn GW, Klawans HC (eds). $\mathrm{H}$ andbook of Clinical Neurology. Elsevier Science: A msterdam, 1985, vol. 47, pp 337-396.

$3 \mathrm{M}$ artin $\mathrm{R}, \mathrm{McF}$ arland $\mathrm{H}$, M cFarlin D: Immunological aspects of demyelinating disease. Annu Rev Immunol 1992; 10: 153-187.

4 Hohlfeld R, Londei M, M assacesi L, Salvetti M: T-cell autoimmunity in multiple sclerosis. Immunology Today 1995; 16: 259-261.
5 Kurtzke JF: MS epidemiology world wide. O ne view of current status. A cta N eurol Scand 1995; S161: 23-33.

6 E bers GC, Sadovnick A D : The geographic distribution of multiple sclerosis: a review. Neuroepidemiology 1993; 12: 1-5.

7 R obertson NP, Fraser M, Deans J, Clayton D, Walker N, Compston DA S: A ge-adjusted recurrence risks for relatives of patients with MS. Brain 1996; 119: 449-455.

8 Ebers GC, Sadovnick AD, Risch NJ and the Canadian Collaborative Study G roup: Familial aggregation in M S is genetic. Nature 1995; 377: 150-151.

9 Sadovnick A D, E bers G C, D yment DA, R isch NJ and the Canadian Collaborative Study Group: Evidence for genetic basis of MS. L ancet 1996; 347: 1728-1730.

10 Dyment DA, Sadnovich A D, E bers G C: G enetics of M S. $\mathrm{H}$ um Mol G enet 1997; 6: 1693-1698.

11 Kuokkanen S, G schwend M, R ioux J D et al: G enomewide scan of M S in Finnish multiplex families. A m J H um G enet 1997; 61: 1379- 1387.

12 Lander ES, Kruglyak L: Genetic dissection of complex traits: guidelines for interpreting and reporting linkage results. N at G enet 1995; 11: 241-247.

13 Sundvall $M$, Jirholt J, Yang $\mathrm{HT}$ et al: Identification of murine loci associated with susceptibility to chronic experimental autoimmune encephalomyelitis. $\mathrm{N}$ at $\mathrm{G}$ enet 1995; 10: 313-317.

14 Roth MP, Viratelle C, Dolbois L et al: Genome wide search identifies two susceptibility loci for experimental autoimmune encephalomyelitis on rat chromosomes 4 and 10. J I mmunol in press.

$15 \mathrm{R}$ isch N, M erikangas $\mathrm{K}$ : The future of genetic studies of complex human diseases. Science 1996; 273: 1516-1517.

16 Nisticò $L$, Buzzetti $R$, Pritchard LE et al: The CTLA-4 gene region of chromosome $2 q 33$ is linked to, and associated with, type 1 diabetes. $\mathrm{H}$ um M ol G enet 1996; 5: 1075-1080.

$17 \mathrm{M}$ arron MP, Raffel LJ, Garchon $H J$ et al: Insulindependent diabetes mellitus (IDDM) is associated with CTLA -4 polymorphisms in multiple ethnic groups. H um Mol G enet 1997; 6: 1275-1282.

18 Piazza A, Mayr WR, Contu L et al: Genetic and population structure of four Sardinian villages. A nn H um G enet 1985; 49: 47-63.

19 Granieri E, Casetta I, Tola M R : E pidemiology of M S in Italy and in Southern Europe. A cta Neurol Scand 1995; S161: $60-70$.

20 R osati G, A iello I, Pirastu M I et al: E pidemiology of M S in north-western Sardinia: further evidence for higher frequency in Sardinians compared to other Italians. N euroepidemiology 1996; 15: 10-19. 
21 Kotsa K, Watson PF, Weetman AP: A CTLA-4 gene polymorphism is associated with both $\mathrm{G}$ raves' disease and autoimmune hypothyroidism. Clin Endocrinol 1997; 46: 551-554.

22 Poser CM, Paty DW, Scheinberg L: New diagnostic criteria for multiple sclerosis: guidelines for research protocols. A nn Neurol 1983; 13: 227-231.

23 D ib C, Faure S, Fizames $C$ et al: A comprehensive genetic map of the human genoma based on 5264 microsatellites. Nature 1966; 380: 152-154.

24 Murray J C, B uetow K H, Weber J L et al: A comprehensive human linkage map with centimorgan density: Cooperative $\mathrm{H}$ uman L inkage Center (CH LC). Science 1994; 265: 2049-2054.

25 K ruglyak L, Daly MJ, R eeve-D aly MP, L ander ES: Parametric and non parametric linkage analysis: a unified multipoint approach. Am J Hum Genet 1996; 58: 1347-1363.

26 Collins A, Frezal J, Teague J, M orton NE : A metric map of humans: 23,500 loci in 850 bands. Proc Natl A cad Sci U SA 1996; 93: 14771-14775; (http://cedar.genetics.soton.ac.uk/ publ.ic - html/gmap.html).

27 Davies J L, K awaguchi Y, B ennett ST et al: A genome-wide search for human type 1 diabetes susceptibility genes. Nature 1994; 371: 130-136.

28 Davis S, Schroeder M, Goldin LR, Weeks DE: Nonparametric simulation-based statistics for detecting linkage in general pedigrees. Am J Hum Genet 1996; 58: 867-880.

29 Davis S, Goldin LR, Weeks DE: SimlBD: A powerful robust non parametric method for detecting linkage in general pedigrees. In: Pawlowitzki I-H, Edwards JH, Thompson EA (eds). G enetic M apping of D isease $G$ enes. A cademic Press: San Diego, CA , 1997, pp 189-204.
30 H aines J L for The M ultiple Sclerosis G enetics G roup: A complete genomic screen for multiple sclerosis underscores a role for the major histocompatibility complex. $\mathrm{N}$ at $\mathrm{G}$ enet 1996; 13: 469-471.

31 Sawcer $S$, Jones $H B$, Feakes $R$ et al: $A$ genome screen in multiple sclerosis reveals susceptibility loci on chromosome $6 p 21$ and 17q22. N at G enet 1996; 13: 464-468.

32 Ebers GC, Kukay K, Bulman DE et al: A full genome screen in multiple sclerosis. N at G enet 1996; 13: 472-476.

33 Kuokkanen S, Sundvall M, Terwilliger JD et al: A putative vulnerability locus to multiple sclerosis maps to 5 p14-p12 in a region syntenic to the murine locus $\mathrm{E}$ ae2. $\mathrm{N}$ at $\mathrm{G}$ enet 1996; 13: 477-480.

34 M arrosu M G, M urru M R, Costa G et al: M ultiple sclerosis in Sardinia is associated and in linkage disequilibrium with HLA -DR 3 and -DR 4 alleles. A m J H um Genet 1997; 61: 454-457.

$35 \mathrm{R}$ isch $\mathrm{N}$ : A ssessing the role of H LA -linked and unlinked determinants of disease. Am J Hum Genet 1987; 40: $1-14$.

36 Todd JA : G enetic analysis of type 1 diabetes using whole genome approaches. Proc Natl A cad Sci USA 1995; 92: 8560-8565.

$37 \mathrm{H}$ aines $\mathrm{J}$, Terwedow $\mathrm{HA}$, B urgess $\mathrm{K}$ et al: Linkage of the $\mathrm{MHC}$ to familial multiple sclerosis suggests genetic heterogeneity. Hum M ol G enet 1998; 7: 1229-1234.

38 R oses A D, D evlin D, Conneally PM et al: Measuring the genetic contribution of $A$ poE in late-onset $A$ lzheimer disease. A m J H um G enet 1995; 57: (suppl.): A 202.

39 Becker K G, Simon R M , B ailey-Wilson JE et al: Clustering of non-major histocompatibility complex susceptibility candidate loci in human autoimmune diseases. Proc $\mathrm{Nat}$ A cad Sci USA 1998; 95: 9979-9984. 